\section{Retocai o céu de}

Anil: sintomas

do desenvolvi-

mentismo na

MPB (1946-1968)

\section{André Luis Carneiro*}

DOI: 10.11606/issn.2318-8855.v10i1p414-440

Resumo: O texto presente soma-se a uma vasta bibliografia acerca do nacionalismo, sua relação com o imaginário popular e, em última instância, com a cultura brasileira. O recorte temporal data do período entre 1946 e 1968, compreendendo sua continuidade com o projeto desenvolvimentista em curso desde os anos de 1930, mas também levando em consideração as rupturas, especialmente após 1964. Os critérios de análise para a cultura de um país periférico são oferecidos por Frantz Fanon em sua obra Os Condenados da Terra, e como fonte dos diferentes imaginários nacionais serão elencadas algumas obras da MPB

Palavras-chaves: Desenvolvimentismo; Identidade nacional; Música Popular Brasileira

* Graduando em História pela Universidade do Estado do Rio de Janeiro. E-mail para contato: andreluis.carneiro130@gmail.com. 


\section{artigos}

Retocai o céu de Anil

\section{Introdução}

Em 2015 Vladimir Safatle escreveu na Folha de São Paulo duras críticas ao estado da música brasileira. O filósofo argumenta que "a ideologia cultural nacional sempre foi, em larga medida, uma ideologia musical" (SAFATLE, 2015, p. 9), aplicando ainda no século XX as estratégias de formação de identidade nacional traçadas no século XIX. Essa lentidão processual seria parte do inócuo desenvolvimento promovido durante a Primeira República. Com os paradigmas da Semana de 22 e o progresso técnico desencadeado em 1930, a música brasileira pode desfrutar de destaque no debate cultural nacional. Seu artigo segue com uma crítica dos momentos pelos quais a música brasileira passou, desde o desenvolvimentismo dos anos 1950 até a decadência neoliberal do século XXI. Na época, o artigo se contrapunha ao argumento de que uma 'popularização da cultura' estaria em curso. Safatle declara:

Ultimamente, todas as vezes que se levanta a regressão da qual a música brasileira é objeto se é acusado de elitista. Afinal, tais músicas teriam vindo dos estratos mais pobres da população brasileira. O que se chora seria, na verdade, o fim da dominância cultural da classe média urbana e o advento das classes populares e das classes do Brasil profundo (SAFATLE, 2015, p. 9).

Essa aplicação de "um esquema tosco de luta de classes ao campo da cultura" foi um dos sintomas latentes do oportunismo intelectual do 'lulismo' já à beira da falência. No entanto, o autor - provavelmente limitado pelo veículo - não estendeu sua reflexão para o estado da indústria cultural brasileira, a sua lógica produtiva e como ela se relacionava dialeticamente com a identidade nacional daqueles anos. Afinal, aquela cultura criticada por Safatle não era um produto externo às condições materiais e políticas da sociedade brasileira; ela se relacionava intimamente com a hegemonia promulgada pelo período de redemocratização. Não obstante, na primeira temporada do 


\section{artigos}

\section{André Luis Carneiro}

programa Esquenta! - vitrine dessa dita "arte popular" à época criticada por Safatle Fernando Henrique Cardoso deu uma entrevista defendendo a descriminalização das drogas, e Lula - no dia 02 de janeiro de 2011, estreia do programa - deu sua primeira entrevista após a sucessão presidencial. Portanto, mesmo em seu pior estado, a música brasileira continua refletindo a realidade nacional.

A indústria cultural seguiu o dinheiro, voltou-se para o campo (leia-se agronegócio) e abriu caminho para o sertanejo universitário. Hoje a música produzida gira majoritariamente em torno do sertanejo universitário, do funk e, sazonalmente, por conta do Carnaval, do samba e do axé. Esse eixo é alimentado por um número de 'operários da composição' musical que produzem de modo propriamente capitalista (em massa e de forma alienada) letras e progressões harmônicas genéricas e que podem facilmente se adaptar a qualquer um desses estilos. Safatle, no entanto, ao atacar o débil e oportunista esquema de classes defendido à época, comete um erro de leitura histórica. Reforço que o veículo limitado provavelmente impediu o autor de desenvolver mais linhas sobre o tema, mas não deixa de ser desconcertante a afirmação: “não há arte proletária, cultura proletária (...) pois, como dizia Marx, os proletários são aqueles que não têm religião, Estado, moral (e acrescentaria música, cultura). Por isso, eles são a indicação do que ainda não tem forma nem imagem" (SAFATLE, 2015, p. 9).

Claro, se nos limitarmos ao que a 'Cultura Oficial do Estado' ou ao que a produção da indústria cultural tem para nos oferecer, realmente não há espaço para o imaginário proletário. Porém a cultura nacional se relaciona de forma dialética também com os elementos não oficiais. Ou seja: a cultura não é apenas o que está dentro da indústria cultural, mas também o que está na margem, na periferia. Os movimentos contraculturais e de vanguarda também compõem o imaginário cultural de uma na- 


\section{artigos}

Retocai o céu de Anil

ção. Podemos estender a compreensão de 'imaginário nacional' se buscarmos com um olhar crítico as raízes dessa produção periférica. E no caso brasileiro, por se tratar de uma nação à margem do sistema capitalista internacional, o imaginário promovido pela vanguarda e pela contracultura talvez seja ainda mais autêntica do que a "oficial" promovida pela indústria cultural. A origem para a regressão musical apontada pelo autor é fruto de nossa dependência econômica.

\section{Nacionalismo em debate}

As eleições de 2022 ocorrerão em meio às celebrações dos 200 anos do grito do Ipiranga. Muito provavelmente temas como independência, soberania, nacionalismo e orgulho patriótico permearão campanhas e debates. A postura vassala do atual presidente da República frente ao império estadunidense e o despreparo da sua diplomacia colocaram a imagem do Brasil em muitas situações vexaminosas já nos primeiros meses de mandato. No entanto, uma pesquisa Datafolha, realizada entre 04 e 05 de setembro de 2019, mostrou que 72\% dos brasileiros têm orgulho da sua nacionalidade. Ainda que longe do ápice registrado ao fim de 2010 (89\%), o Brasil vem apresentando uma subida nos índices de orgulho nacional desde a decadência de junho de 2017 (50\%. Mesmo assim, nenhum analista sente-se confortável em afirmar que o povo brasileiro é nacionalista. Cabe perguntar: o que é o nacionalismo? Qual o seu papel histórico na fundação de Estados-nação? O que esses conceitos significam para a periferia capitalista? Partindo da compreensão de que a nacionalidade se manifesta como um 'artefato cultural', resultado "do cruzamento complexo de forças históricas", Benedict Anderson questionou como esses artefatos tornaram-se uma entidade histórica, a transformação de seus significados no tempo e como "inspiram uma legitimidade tão profunda" (ANDERSON, 1990, p. 13). Sob uma perspectiva antropológica, Anderson entende que o nacionalismo tem uma forte relação com conceitos li- 


\section{artigos}

\section{André Luis Carneiro}

gados à família e à religião. Conclui que as nações são 'comunidades imaginadas', distintas; não como propôs Ernest Gellner, entre "autênticas" ou "falsificadas", mas distintas por estilos de imaginação (ANDERSON, 1990, pp. 13-14). Imaginadas, porém, de forma limitada: por fronteiras e pela alteridade. Imaginadas como soberana: após a devassa do direito divino promovida pelo lluminismo, a legitimidade depende da vontade dos associados à "fé" nacional, do povo. Por fim, imaginadas como comunidade: a nação é sempre concebida como um companheirismo profundo e horizontal, fraternidade que torna possível que milhões de pessoas, não só matem, mas morram voluntariamente.

Partindo da chave analítica oferecida por Anderson, o sociólogo Stuart Hall reformula sua questão: como é imaginada a nação moderna? Que estratégias de representação constroem o sentimento comum de pertencimento e identidade nacional? (HALL, 2006). Hall elenca cinco elementos principais, a saber, 1) A narrativa da nação: como são contados e recontados seu passado, sejam eles históricos ou mitológicos; temas e cenários comuns na historiografia, na literatura, nas mídias e no imaginário popular; 2) A tradição atemporal: elementos essenciais do caráter nacional, imutáveis, unificados e contínuos; 3) A tradição inventada: a (re)formulação de práticas, rituais e simbologias que busque introduzir novas normas e valores; 4) 0 mito fundador: a História vista de cima; e 5) 0 mito popular/folclórico: a História vista de baixo.

O sociólogo jamaicano entende o nacionalismo como um equilíbrio entre glórias passadas e um impulso por avançar em direção à modernidade. Uma conexão ideológica entre passado, presente e futuro; história e memória, que motivam o desejo de pertencer à comunidade e perpetuar sua herança. Esses cinco elementos coincidem com os critérios oferecidos por Eric Hobsbawm para a associação de indivíduos 


\section{artigos}

\section{Retocai o céu de Anil}

enquanto nação e sua decisão de formar um Estado baseado nesse conceito. O primeiro critério é o da história institucional-cultural dos letrados, ou seja, as histórias das elites. Nelas os povos remontam suas tradições mais remotas e encontram (ou fabricam) algo que Ihes dê o mínimo de coesão e coerência. Sejam os antigos Estados-nação, os antigos reinos ou mesmo os antigos impérios (HOBSBAWM, 2017, p. 141). O segundo critério é o princípio de alteridade que operava na lógica de antítese; se os antigos Estados se afirmavam na haute culture, as identidades regionais se afirmaram na cultura do folk, do povo. No entanto, esse folclore não é político em si. Hobsbawm aponta que “onde não havia argumentos históricos para a unificação (...) esta era, quando possível, formulada como um programa" (HOBSBAWM, 2017, p. 143). O nacionalismo operou como uma ideologia no século XIX, capaz de ocupar as lacunas deixadas pelos programas de cunho revolucionário e os de ordem conservadora. Em muitas ocasiões essa ideologia foi disseminada de cima para baixo; pela iniciativa de um líder aristocrata ou mesmo de um rei, como na Alemanha e na Itália; outras por iniciativas burguesas, como na Tchecoslováquia. Esses processos contaram com "vanguardas nacionalistas" que militaram e fizeram circular os ideais fundadores de suas nações. Hobsbawm atenta para a presença de um estrato social intermediário entre as massas e a burguesia como agentes dessa militância. Por fim, viria a adesão dos trabalhadores e camponeses que, segundo o autor, evitavam pisar fora do “caminho traçado pela elite" (HOBSBAWM, 2017, p. 149).

Eric Hobsbawm afirma que a nação "precisava realmente ser construída". Por essa necessidade impõe-se o papel crucial das instituições de Estado para organizar as forças produtivas e oferecer, através do sistema educacional, meios de expandir a cultura nacional. Lord Acton, um observador do século XIX, escreveu, em 1862, que “no antigo sistema europeu, os direitos das nacionalidades não eram reconhecidos 


\section{artigos}

\section{André Luis Carneiro}

pelos governos nem afirmados pelos povos". A nacionalidade não era uma questão tangenciada pela luta em prol da liberdade: os absolutistas se importavam com o Estado; os liberais, com o indivíduo; igreja e nobreza, com a dinastia. A política girava em torno desses temas, e conceitos como 'nacionalidade' ou 'independência' jamais eram contemplados (ACTON, 2000, p. 25). O autor relata que o nacionalismo não se tornou apenas um auxiliar revolucionário, mas "sua substância mais efetiva". Na Revolução Francesa a nacionalidade atuou como fator aglutinador de um povo que havia conquistado a própria soberania (ACTON, 2000, p. 27). A ideia da soberania do povo não controlada pelo passado deu origem à ideia de nacionalidade. Ela brotou da rejeição de duas autoridades: o Estado e o passado (ACTON, 2000, p. 28). Retornando à Stuart Hall, o autor faz três observações que funcionam como balizas para o desenvolvimento das culturas nacionais, a saber, 1) a conquista violenta foi o signo de muitas das unificações nacionais; 2) essas nações sempre vão se constituir de diferentes classes sociais, de grupos étnicos e de gêneros; e 3) a dinâmica de dependência perpetrada pelo sistema colonial e neocolonial criou hegemonias culturais que subjugam culturas periféricas.

Em 2000 Partha Chatterjee afirmava que, após a URSS, o ressurgimento do nacionalismo passou a ser uma ameaça à 'pax liberal'. O autor denuncia a disciplina imposta aos Estados pós-coloniais, em que "desenvolvimento e modernização" transformaram-se em antagonistas do nacionalismo periférico (CHATTERJEE, 2000, p. 227). Na América Latina houve uma 'esterilização' dos nacionalismos, que passaram a ser associados às ditaduras de segurança nacional, e, portanto, entendidos como conceito "autoritário". Líderes anticoloniais que não tiveram sua reputação difamada - como Fidel Castro e Mohammad Mossadegh - ou caíram no ostracismo - o caso de Patrice Lumumba e Thomas Sankara - ou tiveram suas imagens apropriadas às questões 


\section{artigos}

\section{Retocai o céu de Anil}

marginais. Como nota Chatterjee, Gandhi virou um símbolo do pacifismo e vegetarianismo, Ho Chi Minh foi apropriado pela Guerra Fria, Nelson Mandela se tornou o campeão da harmonia racial e Ernesto Guevara se transformou em um ícone de rebeldia genérica. Os princípios nacionalistas de independência, soberania e autodeterminação foram rejeitados pela Europa, e suas manifestações na periferia capitalista foram amplamente denunciadas (CHATTERJEE, 2000, p. 228). Nesse contexto hostil ao nacionalismo, Chatterjee cita o êxito de Benedict Anderson em trazer novas questões relevantes ao debate; no entanto, questiona a tese de Anderson no que se refere às "formas modulares" que estruturam um Estado-Nação. Isto é, o formato e a organização de um Estado moderno são impostos por uma lógica de eficiências e prioridades orientadas pela ordem capitalista internacional: "O que Ihes resta para imaginar?" (CHATTERJEE, 2000, p. 229). Se criar um Estado-Nação fosse como pintar um quadro, o que foi dado para as periferias foram três cores de giz de cera e um livro de colorir velho.

Como sugere o autor, é fundamental entender o que constitui a identidade de cada nação para além da hegemonia colonial (CHATTERJEE, 2000, p. 230). No caso brasileiro, nos deparamos com uma enorme dificuldade de saber quem somos. Diferente da Índia, da China ou mesmo das nações africanas, o Brasil não possui um passado milenar, pois a "inconveniência histórica" da colonização fez com que, mesmo com o honroso esforço desprendido por vários historiadores, o resgate da memória dos povos indígenas seja uma tarefa árdua e ainda pouco conhecida. Então, o Brasil está aí, beirando os 200 anos e ainda sem muito bem saber quem é; desde a fundação do IHGB os debates sobre as "raízes do Brasil" não cessam. Como dizia Darcy Ribeiro: filho do índio, do negro, do branco; não é branco, não é negro e nem é índio. É um ninguém, um "filho da terra" (RIBEIRO, 1995, p .128). Envolto nas celebrações do 


\section{artigos}

\section{André Luis Carneiro}

bicentenário de sua crise existencial, recolhendo os cacos deixados pela pandemia de COVID-19, o Brasil terá de escolher um presidente. Em um país em que a Petrobrás é esquartejada mês após mês pelas vendas ao capital estrangeiro, a Embraer é comprada pela Boeing por um preço similar ao da aquisição do Copacabana Palace à Louis Vuitton, em que a Amazônia é engolida por chamas provocadas por latifundiários que almejam aumentar a exportação de suas monoculturas (e tantas outras desgraças que tornam esses exemplos cotidianamente obsoletos), convém superar os inventários das três raças em busca de um passado glorioso. Nosso passado não é glorioso, nós somos o que somos. Nossa "tradição oficial" até hoje tem sido a superexploração, a dependência e a subserviência internacional; não há nada que possa alterar essa História. Todas as bem-intencionadas tentativas de analisar aspectos identitários das nossas questões de origem limitam-se justamente à suas "sequelas" como destino final de seu trabalho; a condição colonial/dependente é um cenário passageiro ou um meio dessas identidades se afirmarem ou resistirem; passam do ponto como um trabalhador cansado que só acorda duas estações depois do seu destino. Portanto, o bicentenário da independência - e sua convergência com o calendário eleitoral - será ocasião de colocar em pauta, não mais de onde viemos, mas para onde vamos. Será possível aspirarmos o posto de Civilização do Terceiro Milênio sem uma indústria nacional de ponta? Será possível sermos soberanos dependendo exclusivamente da exportação de commodities? Será possível ser independente dedicando $49 \%$ do orçamento do governo federal a juros de dívidas? Será possível sustentar essa vassalagem por mais 200 anos? Será possível solucionar esses problemas sem dar aos trabalhadores maior centralidade na organização das forças produtivas? 2022 dará a chance de pautamos uma revolução à brasileira no debate público; uma revolução que dê motivos e corresponda ao amor já existente em 72\% dos brasileiros. Será a oportunidade de inaugurar a Segunda Independência do Brasil. E se não, seja 


\section{artigos}

Retocai o céu de Anil

lá quem for eleito, fará em $1^{\circ}$ de janeiro de 2023 mais um juramento vazio, desprovido de compromisso com o Art. 78 da Constituição de 1988, “a união, a integridade e a independência do Brasil" (Brasil, 1988).

\section{Nacionalismo e Cultura em Frantz Fanon}

“Nenhuma proclamação da cultura nos eximirá de nossas tarefas fundamentais, que são a libertação do território nacional" (FANON, 1979, p. 196). Nascido na Martinica Francesa, em 1925, Frantz Fanon tornou-se um dos mais influentes pensadores na luta anticolonial. Seu trabalho trouxe uma gigantesca contribuição ao conectar psicologia e filosofia política com uma prática radicalmente revolucionária. Fanon foi um pan-africanista e um marxista-humanista engajado em analisar criticamente as relações entre colonos, colonizadores e colonizados e suas consequências sociais, culturais e psicológicas. Seu primeiro trabalho, intitulado Ensaio Sobre a Desalienação do Negro e inspirado na experiência pessoal de Fanon como um doutorando negro de uma universidade francesa, causou impacto. Como sua tese acabou sendo rejeitada, o autor publicou-a como livro. Quando o filósofo e editor francês de esquerda, Francis Jeanson, leu a obra, entrou em contato com Fanon para propor a publicação sob um novo título: Pele Negra, Máscaras Brancas. Este livro discorre sobre a constante reprovação dos negros na sociedade branca francesa, o complexo de inferioridade gerado naqueles homens e mulheres, e como a não integração de negros migrantes tem muitas outras barreiras para além da língua. Em 1953, Frantz Fanon trabalhava no hospital psiquiátrico Blida-Joinville, na Argélia, um ano antes de eclodir a revolução; em 1955, Fanon se juntou à Frente de Libertação Nacional. Acumuladas as missões de tratar de soldados francês e torturados argelinos, o autor decide renunciar ao seu posto no hospital francês e dedicar-se aos esforços de libertação do povo argelino. Nesse contexto escreve Os Condenados da Terra, lançado no final de sua vida, em 


\section{artigos}

\section{André Luis Carneiro}

1961. Esse livro ficou amplamente conhecido no mundo pela defesa do uso da violência como instrumento na luta de libertação. O testemunho do autor, em meio a uma de tantas guerras de descolonização que tomaram o mundo após a $2^{\circ}$ Guerra Mundial, captou com sensibilidade a contradição humana que existia entre colonizadores e colonizados. Essa advocacia da violência fez com que o livro fosse censurado pelo governo francês. Em meio à toda a controvérsia gerada na metrópole, foi o existencialista Jean Paul Sartre quem melhor soube compreender a obra. No prefácio que posteriormente escreveu para o livro, Sartre é categórico: “Esta não é uma obra para franceses".

Os Condenados da Terra é também um alerta para os percalços do processo de descolonização no contexto de transição do neocolonialismo para a globalização. Destaca-se o capítulo 4 - Sobre a Cultura Nacional - em que Fanon faz uma primorosa análise sobre a evolução e a importância da cultura, da política e da cultura política no convívio e no conflito entre colonizados e colonizadores. Fanon abre esse capítulo anunciando que toda geração tem sua missão histórica: a de seus pais foi debater da forma que puderam, e se seus legados não repercutiram internacionalmente resta entender o motivo; a sua seria regular todas as revoltas (FANON, 1979, p. 171). Em seguida propõe uma análise acerca dos problemas de legitimidade da reivindicação nacional, a qual, uma vez estabelecida entre partido e povo, mobiliza e convida para a ação (FANON, 1979, p. 172). Para enfrentar essa primeira fase da luta nacional, o coIonialismo recorre ao economicismo; simula preocupação com a sorte de um povo que julga tão indefeso e de um território que diz ser tão pobre - mas que são fortes e ricos o suficiente para aguentar séculos de exploração -, até perceber que suas reformas não satisfazem as aspirações do povo colonizado. "Vale mais a fome com dignidade que o pão na escravidão", arremata Fanon (FANON, 1979, p. 173). 


\section{artigos}

Retocai o céu de Anil

O autor identifica uma contradição do discurso colonial: nações coloniais como França, Alemanha e Inglaterra afirmaram-se e tiveram o reconhecimento de suas culturas nacionais, atestando na prática a importância deste conceito para o desenvolvimento; mas (como foi dito posteriormente por Chatterjee), elas denunciam nacionalismos periféricos e, quando superado o fracasso de suas ameaças economicistas, partem para o discurso apocalíptico, prevendo um "retorno da barbárie". Como toda contradição política, essa não foge à regra quanto a sua utilidade para reforçar o domínio de classe. A complexidade étnica do continente Africano, agravada pela diáspora, faz com que Frantz Fanon considere limitada uma orientação meramente identitária como guia das lutas, levando-as inexoravelmente a um "beco sem saída" (FANON, 1979, p. 178). Assim como um “doisladismo", que busca dividir erros e acertos entre colonizadores e colonizados, como se ambos estivessem em pé de igualdade na condução de seus destinos (FANON, 1979, p. 181). Esse pensamento é estéril, inócuo, universalista, conciliar, provando-se totalmente inútil quando posto em prática.

Esse fenômeno opera como um recalque político, uma tentativa desesperada de alterar a realidade para acomodar soluções confortáveis. É um “desvio de rota” que, apesar do seu valor pedagógico, prolonga o caminho da revolução. Uma vez completo esse desvio de rota - ou seja, uma vez que a realidade se impôs e nenhuma conciliação foi capaz de solucionar os problemas - resta ao colonizado duas alternativas: resignar-se ou reagir. Fanon afirma que o colonizado começa sua reação redescobrindo seus signos e renegando todos os símbolos e gestos da cultura ocupantes: “Reencontrar o povo é fazer-se árabe, fazer-se o mais indígena possível, o mais irreconhecível, é cortar as asas que se tinha deixado crescer" (FANON, 1979, p. 183). Fanon analisa a cultura colonizada passando por três etapas, da sua evolução até a fase nacional-libertadora (FANON, 1979, p. 185): 1) Assimilação exterior: Trata-se da ab- 


\section{artigos}

\section{André Luis Carneiro}

sorção da cultura dominante. Neste processo o colonizado fetichiza tudo o que lhe é estrangeiro. Não necessariamente com a mesma conotação sexual que Fanon discute em Pele Negra, Máscaras Brancas, ainda que haja um diálogo possível entre os dois, mas certamente como a manifestação de uma idolatria que garante ao colonizado um falso sentimento de pertencimento daquela cultura que não é a sua. É o momento em que o artista colonizado tenta emular o artista colonizador, copiando sua estética, sua temática e o que mais for necessário para que o colonizador lhe garanta reconhecimento; 2) Recordação interior: É o processo de imersão do artista colonizado na sua cultura pré-colonial ou naquilo que se tornou periférico após a ocupação. É uma etapa interessante, em que a conexão entre passado e presente ativa a criatividade e gera necessárias discussões sobre identidade e comunidade. No entanto, esse processo pode facilmente entrar em um ciclo vicioso, o que faz com que a metáfora do pântano empregada por Fanon ganhe um outro significado. É fácil ficar preso nessa etapa; como argumentado anteriormente, o Brasil passou por 200 anos de crise existencial tentando elucidar o que constitui sua identidade. Vivemos hoje uma nova fase da afirmação da identidade negra e originária deste país; uma fase em que constatamos avanços consideráveis a nível de debate, porém, a nível prático, restringe-se a meras políticas públicas e a movimentos sociais de pouca eficiência. De todo modo, é o maior avanço desde a afirmação da controversa 'democracia racial' e as teses de Gilberto Freyre dos anos de 1930. A luta anticolonial precisa ser a luta identitária somada à guerra de classes. Frantz Fanon é muito claro ao afirmar que o colonialismo jamais se envergonhará diante de uma cultura estrangeira; portanto a cultura em si não é uma força capaz de conduzir uma luta nacional mas tem a capacidade de evidenciar esse combate (FANON,1979, p. 185). O autor se opõe enfaticamente às tradições requentadas que em nada conectam-se ao seu povo. Referindo-se às artes plás- 
Retocai o céu de Anil

ticas, colonizadas como "reprodução estereotipada", Fanon antecipou o que Edward Said viria anos mais tarde chamar de 'orientalismo' (FANON, 1979, p. 186):

"Só se pode avançar resolutantemente quando antes de tudo se toma consciência de sua alienação. Nós absorvemos tudo do outro lado. Mas o outro lado não nos dá nada sem, através de mil rodeios, nos curvar em sua direção (...) Absorver é também, em múltiplos planos, ser absorvido."(FANON, 1979, p. 188);

e 3) Agitação exterior: Por fim, esta etapa se manifesta como a ação do imaginário nacional. O artista colonizado parte para o combate direto com seu colonizador. A imersão na etapa anterior tem o intuito de romper qualquer barreira entre a experiência do artista e de seu povo, fazendo com que nela sua arte emerja diretamente dessa experiência. Porém, mais do que a acusar a exploração - que certamente constitui um estágio importante entre as fases 2 e 3 - Fanon exprime a necessidade de que um autêntico artista nacional ofereça uma perspectiva de futuro. Sua perspicácia deve estar sempre atenta para denunciar o perpetrador da miséria do seu povo; sua criatividade deve oferecer ao seu povo a visão de um novo tempo. O artista, como agente revolucionário, é o mais autorizado para trabalhar com utopias:

"O homem colonizado que escreve para seu povo deve, quando utiliza o passado, fazê-lo com o propósito de abrir o futuro, convidar à ação, fundar a esperança (...) para lhe dar densidade, é preciso participar da ação, engajar-se de corpo e alma no combate nacional."(FANON, 1979, p. 193).

Portanto, Frantz Fanon compreende que qualquer defesa de uma cultura nacional periférica deve ser uma luta pela libertação nacional, que combine "esforços feitos por um povo no plano do pensamento para descrever, justificar e cantar a ação atra- 
André Luis Carneiro

vés da qual o povo se constituiu e se manteve" (FANON, 1979, p. 194), orientada pelo ritmo do seu povo, com a constante tarefa de ajudar-Ihe a conceber o futuro.

\section{A MPB nos tempos do desenvolvimentismo sob o olhar de Frantz Fanon}

Ao propor essa perspectiva de análise, Fanon tinha em mente um país cuja luta de libertação e construção nacional estivesse em curso. Portanto, a evolução das etapas estaria ligada ao avanço do processo histórico. Transpondo essa visão para a História do Brasil, dificilmente encontramos um momento comparável ao que pensava Fanon, mas isso não significa que seus critérios de análise e seu modelo de crítica não se apliquem. Como disse o historiador Marcos Napolitano:

“Num dos países mais ricos em diversidade sonora do mundo (...) dedicar-se à história da música, pensada em diálogo com a história intelectual, social, política e cultural, é dar um passo a mais na compreensão da própria sociedade e suas formas de auto-representação."(NAPOLITANO, 2007, p. 171, grifo nosso).

Por isso o recorte escolhido para este trabalho data do período entre 1946 e 1968. Além de ser um período consagrado na historiografia, trata-se justamente dos anos do chamado desenvolvimentismo. Em maior ou menor grau veremos que elementos de uma sociedade em rápido desenvolvimento permearam as letras de canções populares da época. Para evitar um prolongamento desnecessário vamos elencar um exemplo para cada etapa proposta por Fanon. É importante ter em mente que, a pretexto de ilustração, foram elencados momentos pontuais da carreira dos cantores, compositores e da MPB como um todo, o que não significa que suas propostas artísticas e estéticas não variaram ao longo do tempo. Tão pouco significa propor que a 'linha evolutiva da MPB' evoluiu de forma cartesiana e teleológica. A ordem 


\section{artigos}

Retocai o céu de Anil

cronológica dos exemplos mais tem a ver com o caminhar da sociedade brasileira do que um movimento pensado e articulado pelos artistas de então. O corte a partir de 1946 deve-se pelo início de um período de redemocratização pós-guerra, e seu fim em 1968 justifica-se, além do Al-5, pelo marco que representou a prisão de Gilberto Gil e Caetano Veloso, o fim abrupto do projeto tropicalista por conta do exílio dos dois, e o avanço de um modelo de produção fonográfico industrial que resultou no estado atual exposto na introdução do texto.

Farnésio Dutra e Silva ganhou popularidade no final dos anos 1930 interpretando canções estrangeiras na rádio Cruzeiro do Sul, no Rio de Janeiro. Para ganhar credibilidade perante o público adotou o nome artístico de Dick Farney. Cantou nos principais palcos da elite carioca, tal como o Cassino da Urca e o Copacabana Palace. Sua voz imponente servia muito bem para as canções que importavam o estilo do jazz/big band das rádios estadunidenses. Sua canção Copacabana, de 1946, é, ainda que com muita ternura, um anúncio turístico:

\footnotetext{
Existem praias tão lindas, cheias de luz Nenhuma tem o encanto que tu possuis

Tuas areias

Teu céu tão lindo

Tuas sereias

Sempre sorrindo.

Copacabana, princesinha do mar

Pelas manhãs tu és a vida a cantar

E à tardinha, o sol poente

Deixa sempre uma saudade

Na gente.
}

É interessante notar que a canção foi lançada no mesmo ano em que se iniciou o governo do General Dutra. Como é conhecido, Dutra proibiu os cassinos, e o Copacabana Palace tornou-se uma grande atração turística e um grande palco para os cantores da época. Essa fase inicial da carreira de Dick Farney estava completamente 


\section{artigos}

\section{André Luis Carneiro}

submetida aos padrões estéticos do estrangeiro, feita para ecoar nos salões da elite carioca que buscava agradar os turistas e legitimar sua modernidade perante a metrópole capitalista, contratando artistas que almejavam seguir os passos de Carmem Miranda e tornar-se populares internacionalmente. Não Ihes ocorria que esta era - e ainda é - reconhecida menos pelo seu talento indiscutível do que pelo exotismo do seu sotaque e da sua estética. Era uma tentativa de emular a haute culture moderna, que vinha dos Estados Unidos e fazia o contraste sugerido por Hobsbawm com a cultura do folk que emanava dos morros. Já naquela época, as escolas de samba, que tinham apelo popular e compositores com o histórico enraizado na experiência do povo, como Cartola, emplacavam seus primeiros sucessos. Apesar das tentativas de apropriação desde o Estado Novo, o samba ainda tinha um longo caminho para uma ampla aceitação por parte das elites. O samba-canção - experimentado por Farney ensaiou uma conciliação que era progressivamente rejeitada pela elite. Até que surge, em 1958, João Gilberto com a canção e o posterior disco homônimo Chega de Saudade. Com a simplicidade da voz e violão, resgatando a batida do samba na harmonia jazzística de seu violão, João Gilberto - tal qual propõe Fanon - inadvertidamente mergulhou nas raízes da música brasileira e criou um novo horizonte nacional. A música não era mais exclusividade de orquestras e cantores teatrais, com suas vozes imponentes, preenchendo salões da elite brasileira. Era também um elemento das camadas médias, que, por conta do desenvolvimentismo e da industrialização nacional, empilhavam-se em apartamentos, mas que poderiam desfrutar, neste momento, de canções sussurradas sem perturbar os vizinhos. 'Desafinado' é um exemplo de como João Gilberto transformou a audição do público sem, como argumentava Theodor Adorno, regredir musicalmente (ADORNO, 1983). Claro, as músicas eram mais simplificadas em termos de arranjo, mas não em relação a sua harmonia: 
Retocai o céu de Anil

\author{
Se você disser que eu desafino, amor \\ Saiba que isso em mim provoca imensa dor \\ Só privilegiados têm ouvido igual ao seu \\ Eu possuo apenas o que Deus me deu \\ Se você insiste em classificar \\ Meu comportamento de antimusical \\ Eu mesmo mentindo devo argumentar \\ Que isto é bossa nova, que isto é muito natural \\ O que você não sabe nem sequer pressente \\ É que os desafinados também têm um coração
}

Apesar de não ter nada de desafinado, João Gilberto abriu as portas da arte musical para além do padrão técnico. Em contraste com Farney - que também fez seu sucesso - a Bossa Nova de João Gilberto é até hoje associada à uma época áurea para o Brasil. Esse reconhecimento se dá não apenas pela sua qualidade objetiva, mas por espelhar a então crescente vida urbana do povo brasileiro. Vale lembrar que Juscelino Kubitschek, eleito dois anos antes do lançamento de Chega de Saudade, ganhou o apelido de 'presidente bossa nova'. A conquista da Copa do Mundo de 1958, o advento da Bossa Nova e a inauguração de Brasília deu ao país um ar de modernidade legitimamente brasileira. Como apontou Roberto Schwarz, o Brasil estava 'irreconhecivelmente inteligente' (SCHWARZ, 2014, p. 18). Em sua visão "o artista buscaria a sua força e modernidade na etapa presente da vida nacional, e guardaria quanta independência fosse possível em face do aparelho tecnológico e econômico, em última análise sempre orientado pelo inimigo." (SCHWARZ, 2014, p. 27). O inimigo, no caso, era a burguesia nacional que não soube tirar proveito desse momento em favor de um projeto nacional. Logo ela começaria a se ressentir com a democratização do desenvolvimento brasileiro e da cultura popular. Iniciativas como o MCP em Recife e os CPC's organizados pela UNE passaram a rivalizar e, muitas vezes, superar a cultura produzida dentro dos círculos tradicionais da elite, que progressivamente aceitavam a 


\section{artigos}

\section{André Luis Carneiro}

bossa nova. Como recorda Schwarz, "este breve período em que polícia e justiça não estiveram simplesmente a serviço da propriedade as questões de uma cultura verdadeiramente democrática brotaram por todo canto."(SCHWARZ, 2014, p. 18).

Com a proposta de democratização do desenvolvimento trazida por João Goulart, a juventude engajou-se no projeto de cultura nacional, disputando um modelo de modernidade popular. Nomes como Nelson Werneck Sodré, Carlos Vereza e outros gigantes da cultura brasileira somaram-se ao projeto criado dentro da iniciativa Teatro de Arena. Com o golpe de 1964 a tarefa imediata do CPC transitou dessa formulação de um imaginário nacional popular para a resistência contra a ditadura. Nessa ocasião surge o espetáculo Opinião, e nomes como Nara Leão, Zé Kéti, Capinam, Torquato Neto e Maria Bethânia emergem como vozes de uma geração que era lentamente sufocada pelo pisar do coturno. Por outro lado, a emergência da televisão como um veículo popular condiciona a produção musical a uma lógica cada vez mais industrial. Apesar dos pesares da ditadura, o período entre 1964 e 1969 é marcado pelos festivais, pelos musicais de televisão e pelo surgimento de nomes como Elis Regina, Edu Lobo, Roberto Carlos, Caetano Veloso e Gilberto Gil. Neste contexto, o paradigma da primeira etapa de Fanon, que buscava emular a estética estrangeira, estava virado de cabeça para baixo. As críticas feitas a quem quer que ousasse ceder à música estrangeira eram severas, o que, no entanto, não impediu que uma invasão acontecesse. A crescente popularidade da Jovem Guarda levou seu show rival, o Fino da Bossa, a reformular o nome para Frente Única da MPB e realizar a infame Marcha Contra a Guitarra Elétrica. No entanto, o imaginário da MPB se afastava da chave de análise proposta anteriormente e a terceira etapa da arte revolucionária de Frantz Fanon tornava-se distante. Na medida em que a invasão estrangeira, a repressão da ditadura e a indústria cultural ganhavam força, as propostas e imaginários de moder- 


\title{
artigos
}

Retocai o céu de Anil

nidade popular já não competiam em pé de igualdade. Ainda assim é possível elencar um exemplo que se encaixa no paradigma fanoniano. Em maio de 1967, chegou às lojas de discos o álbum Louvação, de Gilberto Gil. A terceira música do lado B, Viramundo, parceria de Gil com o poeta mineiro José Carlos Capinam, contém o seguinte trecho:

\author{
Sou viramundo virado \\ Pelo mundo do sertão \\ Mas inda viro este mundo \\ Em festa, trabalho e pão \\ Virado será o mundo \\ E viramundo verão \\ O virador deste mundo \\ Astuto, mau e ladrão \\ Ser virado pelo mundo \\ Que virou com certidão \\ Ainda viro este mundo \\ Em festa, trabalho e pão
}

Em poucos versos Gil e Capinam nos oferecem um sopro de esperança, anunciando que os antigos "viradores" do nosso mundo - astutos, maus e ladrões - serão virados novamente por um mundo que, com certidão, se vira em festa, trabalho e pão. O arremato dos versos remete ao lema político "paz, pão e terra", e, como propôs Fanon, funda uma nova esperança. No entanto, essa música é exceção em seu contexto, que é fortemente marcado por elementos da segunda etapa, tecendo críticas e "resgatando raízes". No ano seguinte, 'Edu canta Zumbi' lança a obra teatral do CPC no mercado fonográfico. Surge também, em 1968, Tropicália ou Panis Et Circenses, disco colaborativo idealizado por Caetano Veloso e Gilberto Gil. Essa obra tentou solucionar a contradição entre música popular e cultura de massas, ao mesmo tempo que propunha "domar" as influências estrangeiras e submetê-las a um imaginário de modernidade nacional. A inserção da guitarra elétrica com ritmos tradicionais da música nordestina 


\section{artigos}

André Luis Carneiro

e caipira desagradou a esquerda universitária; as performances espalhafatosas e controversas desagradaram a direita. O tropicalismo pretendia ramificar a linha evolutiva da MPB, e, em certa medida conseguiu, mas as possibilidades mais amplas foram abortadas em 1969 com a prisão e posterior exílio de Gil e Caetano.

A repressão da ditadura não só quebrou a evolução orgânica da música popular brasileira e sua importância para a formulação do imaginário nacional, mas também submeteu todos os músicos às vontades da indústria cultural. Esteve representada pelas redes de televisão e pela emergência das gravadoras multinacionais, que adentraram o mercado brasileiro na década de 1960 e 1970. É nesse momento que começa a regressão apontada por Safatle no início deste artigo. Durante a década de 1970 e 1980 sopros de genialidade surgiram; os Novos Baianos, o Clube da Esquina e compositores como Belchior deram sobrevida ao imaginário de modernidade popular pré-68, mas com a geração do Rock Brasil (Paralamas do Sucesso, Legião Urbana, Kid Abelha etc.), a regressão das etapas fanonianas se aprofundou amplamente, e o paradigma musical brasileiro, de modo geral, retornou à primeira etapa, emulando as bandas de punk e new wave que surgiam do estrangeiro. Somente nos anos de 1990 a música brasileira voltaria a "avançar". As próprias influências estrangeiras não vinham mais dos grandes nomes do pop internacional, mas desses movimentos contraculturais que emergiram dentro da metrópole capitalista. ${ }^{1}$ Planet Hemp, O Rappa, Racionais MC, Nação Zumbi e tantos outros souberam mesclar o rap, o reggae e o rock com o samba e o maracatu, criticando a desigualdade social e a violência do neoliberalismo hegemônico. No entanto, nem mesmo esses nomes de enorme talento foram

\footnotetext{
${ }^{1}$ Um movimento contracultural na metrópole capitalista dispõe de meios materiais que permitem uma maior disseminação da sua voz. Isso significa que, até pelo menos a década de 90, mesmo nomes como Tupac Shakur contavam com gravadoras cujos rappers eram também emergentes. Essa definitivamente não era a realidade brasileira. Em todo caso, levariam alguns anos até que essas gravadoras alternativas se tornassem influentes na indústria, tal como a Death Row Records.
} 


\section{artigos}

\section{Retocai o céu de Anil}

capazes de realizar a terceira etapa de Fanon e oferecer à imaginação do público a superação das opressões e mazelas da periferia capitalista e a imagem de um mundo novo e livre. Isso se explica por uma série de razões: em primeiro lugar, como dito anteriormente, Fanon descreve tal esquema visando uma nação em pleno processo de libertação e construção de uma nação nova. Não foi o caso do Brasil nem mesmo durante a redemocratização. Em segundo lugar, nenhum artista tem outra pretensão ao lançar-se em carreira que não seja sobreviver. Inertes nesse moinho industrial muitos dos artistas dessa geração acabaram dragados, esmagados ou escanteados. Nos anos 2000 toda a originalidade das cenas contraculturais foram apropriadas e desfiguradas para consumo massivo por meio das rádios e televisões que permaneciam desde a década de 60 como único palco capaz de conectar o artista ao público e chancelar seu sucesso.

O balanço desses anos é que, apesar dos avanços técnicos, quem dava as cartas e determinava o que seria ouvido pelo povo ainda eram as gravadoras e distribuidoras, como Sony e Warner. O maior nome nacional no mercado à época era (e continua sendo) a Som Livre, que se abriga no guarda-chuva da Globo Organizações e Participações S.A. Ou seja, por meio século o elemento de maior influência na identidade nacional era controlado por empresas multinacionais de capital aberto sem nenhum compromisso com a realidade material do povo brasileiro. Isso não significa dizer que não emergiram artistas do povo ou com apelo popular nesses anos, muito pelo contrário. Mais do que nunca, a música brasileira perdia qualquer resquício de modernidade própria que lhe restava do pré-1968. Na verdade, aquele momento da música brasileira chegou a sofrer uma espécie de mistificação: entre os anos 1980 e 2000 era comum ouvir dos apologistas da regressão musical frases como "esse monte de acorde e palavras difíceis é coisa de Chico Buarque ou de Edu Lobo". Ao passo que 


\section{artigos}

\section{André Luis Carneiro}

legitimavam aquela época enquanto geração de ouro, a qualidade da produção musical ficava cada vez mais tosca. Uma tendência da indústria cultural dos anos 2000 foi uma (re)alienação entre compositor e intérprete, e, com isso, a proliferação de artistas sem conteúdo ou mensagem. Até mesmo a ideia de música de protesto parece ter congelado em covers de Que País É Esse, ao passo que muitos ignoravam a qualidade da crítica feita apenas 10 anos antes em músicas como Zerovinteum. De resto, emerge da própria indústria cultural uma miríade de axés, funks e pagodes que possuem uma tradição popular remota e um apelo entre o povo, mas que são tão autênticos e comprometidos com o imaginário nacional quanto uma lasanha de microondas é comprometida com a culinária italiana. Seu sentido não é outro senão abastecer o consumismo crescente na economia brasileira.

O que nos traz de volta ao momento criticado por Safatle e apresentado no começo do artigo. Na medida em que o capital no Brasil movia-se do litoral para o interior, o mesmo ocorria com a música. Em 2012 o petróleo despencou 2,35\%' ao passo que a soja subiu $41 \%$. Ressalto esse ano pois é um marco conhecido do surgimento do sertanejo universitário, que teve a música Ai Se Eu Te Pego como carro chefe. O funk carioca entrou num ponto baixíssimo, em que os produtores nem se davam mais o trabalho de fazer batidas, gravando loops de beatbox de qualidade questionável. A música paulista respirava com algum frescor graças ao surgimento de nomes como Emicida e Criolo, mas nenhum deles possuía a força, isto é, o dinheiro, que empurrava a música do campo. De 2015 para cá o cenário deixou de ser tão dominado pelo sertanejo universitário graças a uma força que, apesar de reverberar na dita esquerda brasileira, é original da sociologia norte-americana: o identitarismo. Como disse Asad Haider, “a política identitária é um método individualista. Ela é baseada na demanda individual por reconhecimento e toma essa identidade individual como 


\section{artigos}

Retocai o céu de Anil

ponto de partida" (HAIDER, 2019, p. 49). É o que tem dado força para artistas como Anitta, Ludmilla, Pabllo Vittar e por um novo frescor na música interiorana com o surgimento do "feminejo". Esses artistas caminham sob uma linha tênue que ora ofende os padrões da sociedade patriarcal, ora os reforça. Não querem nada além de um lugar ao sol num tempo polarizado, em que a rejeição é tão importante quanto o sucesso. O conflito gerado pela identidade dessas novas personagens da música brasileira não tem nenhuma relação com um projeto de imaginário nacional mais progressivo, nem mesmo de empoderamento feminino ou de representatividade desta ou daquela identidade individual. Trata-se de gerar dividendos para acionistas de gravadoras.

\section{Conclusão}

Como dito anteriormente, os exemplos elencados ao longo do texto seguem em ordem cronológica respectiva à produção dos fonogramas e, também em ordem de exemplo, às etapas propostas em Os Condenados da Terra. Os quase 20 anos entre Farney e Gil foram elencados pela sua contemporaneidade com o desenvolvimentismo do pós-guerra, momento histórico em que o Brasil - ainda que não nos mesmo termos de Fanon - imaginou um novo horizonte. Contudo, reforço: nem a 'linha evolutiva da MPB', nem as fases de Frantz Fanon devem ser encaradas de forma cartesiana ou teleológica. Trata-se de um processo social, e, tal como todo processo social, está sujeito a avanços e retrocessos. Não estando subscrito em um amplo processo de libertação e construção nacional, limitando-se apenas à uma dimensão analítica, esses critérios podem encontrar exemplos de qualquer uma das fases ao longo de toda a História. Não obstante, sua pertinência reside no fato de permitir a definição de conceitos para uma arte libertadora, não no sentido meramente individual, mas num sentido coletivo e, até mesmo, utópico. 


\title{
artigos
}

André Luis Carneiro

Oferecer a imagem de uma utopia já não é uma tarefa simples sob condições normais de temperatura e pressão, quem dirá em um momento cotidianamente distópico da história da humanidade. Para muitos é difícil imaginar um futuro, seja ele qual for, e certamente a indústria cultural é uma das milhares de barreiras erguidas contra as nações periféricas, tal como apontou Chatterjee. Por isso é na periferia que encontraremos um imaginário original, é de lá que vem um sopro de esperança. É comum ouvir versos de poesia slam nos trens e metrôs das grandes cidades, como Rio de Janeiro e São Paulo. Arrisco dizer que essa é hoje a nossa mais autêntica manifestação de identidade nacional, afinal, é da periferia que sai a imagem de um país periférico como o nosso. Os versos são contundentes, agressivos e sarcásticos, refletindo a contundência, a violência e a ironia da vida cotidiana daqueles que tudo produzem, mas que nada possuem. Um exemplo está disponível pelo coletivo Rimadores de Vagão, que atua no metrô do Rio de Janeiro. O poema Racismo dispõe dos seguintes

versos:

\author{
Ei, viu, mais uma casa caiu. \\ São milhares sem moradia \\ E o governo, alguém viu? \\ Não ligam para os civis, \\ só se seguir os esquemas \\ Num país sem pena de morte, \\ mas que tem a morte sem pena \\ Dá pena \\ Moradores sem moradia \\ A fome matando por dia e \\ No Brasil, de graça, só a antena \\ E o sistema? Rouba mais! \\ Tem mais operação no morro \\ do que nos hospitais.
}

Nos versos destacados há uma sucessão de críticas: sobre as pessoas sem casa, ou ainda aquelas que escolhem dormir nas ruas para não precisarem pagar o preço extorsivo do transporte público; ao Estado burguês, que só se faz presente na vida do povo pobre para mantê-lo na linha; ao conglomerado midiático, que oferece antenas de transmissão digital para que o povo não perca as cenas do próximo capítulo da desgraça nacional etc. Os versos seguem por quase 4 minutos, expondo por meio de poesia e atuação a vida de um povo que precisa fingir que está tudo bem para se- 


\section{artigos}

Retocai o céu de Anil

guir em frente, nem que o "em frente" seja apenas a próxima estação. Mas, apesar do talento inquestionável desses e de tantos outros artistas que tecem críticas sobre a miséria brasileira, surge como tarefa histórica dos artistas políticos imaginar uma nova comunidade, uma nova nação. É a tarefa dessa geração de artistas criar o “novo Viramundo", afinal, a genialidade é a saída criativa em momentos de desespero.

\section{Referências Bibliográficas}

ACTON, John Dalber. Nacionalidade (1862): Um Mapa da Questão Nacional. Org. Gopal Balakrishnan, 2000.

ADORNO, Theodor. 0 fetichismo na música e a regressão da audição. In: Textos escolhidos (Os Pensadores) Walter Benjamin, Max Horkheimer, Theodor W. Adorno, Jürgen Habermas; traduções de José Lino Grünnewald ... [et al.]. São Paulo: Abril Cultural, 1983.

ANDERSON, Benedict. Nação e Consciência Nacional. São Paulo: Ed. Ática, 1990.

CHATTERJEE, Partha. Comunidade imaginada por quem? In: Balakrishnan, G. Um mapa da questão nacional. Rio de Janeiro: Ed. Contraponto, 2000.

FANON, Frantz. Os Condenados da Terra. Rio de Janeiro: Civilização Brasileira, 1979.

FORMIGONI, Ivan. Preço da soja: comportamento ano a ano no Brasil. Farmnews. 02 de maio de 2016. Disponível em: http://www.farmnews.com.br/mercado/preco-dasoja/. Último acesso em: 07/04/2020. HAIDER, Asad. Armadilha da identidade: raça e classe nos dias de hoje. São Paulo: Veneta, 2019.

HALL, Stuart. A identidade cultural na pós-modernidade. Rio de Janeiro: DP \& A, 2006. 


\section{artigos}

André Luis Carneiro

HOBSBAWM, Eric. A Era do capital, 1848-1875. Rio de Janeiro/São Paulo: Paz e Terra, 2017.

NAPOLITANO, Marcos. História e música popular: um mapa de leituras e questões. Revista de História, São Paulo, n. 157, pp. 153-171, 2007. Disponível em: https://revhistoria.usp.br/index.php/edicoes/55-rh-157-v15-55.

OTIMISMO COM A SITUAÇÃO ECONÔMICA DO PAÍS E PESSOAL SEGUEM RECUANDO. Folha de S. Paulo, São Paulo, julho de 2019. Disponível em: http://media.folha.uol.com.br/datafolha/2019/07/08/9e346cb3192dbc15d6f2d836855 7c318idc.pdf. Último acesso em: 06/04/2020.

PRODUÇÃO DE PETRÓLEO NO BRASIL EM 2012 CAIU 2,35\%, DIZ ANP. Globo Comunicação e Participações S.A, Rio de Janeiro, 04 de fevereiro de 2013. Economia. Disponível em: http://g1.globo.com/economia/noticia/2013/02/producao-de-petroleo-nobrasil-em-2012-caiu-235-diz-anp.html. Último acesso em: 07/04/2020.

RIBEIRO, Darcy. $\quad$ Povo Brasileiro. São Paulo: Global, 2015. SAFATLE, Vladimir Pinheiro. O fim da música. Folha de S. Paulo, São Paulo, 09 de outubro de 2015.2 Disponível em: http://feeds.folha.uol.com.br/fsp/ilustrada/235828-o-fim-da-musica.shtml.

SCHWARZ, Roberto. As ideias fora do lugar: ensaios selecionados. São Paulo: Penguin Classics Companhia das Letras, 2014. 